\title{
Teacher Candidates and Supervising Teachers' Opinions about Activities of Teaching Practice in Elementary Schools
}

\author{
Erten GÖKÇE* \\ Canay DEMIRHAN **
}

\begin{abstract}
The basic aim of this research is to determine the opinion and proposal of supervising teachers and teacher candidates about activities of teaching practice in elementary education schools. This study is a kind of descriptive research. Research data are to gather by questionnaires that are developed by researchers in $2003-2004$ school year second semester with 80 supervising teachers and 341 teacher candidates. Frequency and percentage are used in data analysis. Results of the research are; the cooperation between supervising teacher, teacher candidate and university member is not in a sufficient level; supervising teachers are not enough supportive in the period of developing materials and lesson plans and in addition to this, there is a meaningful difference between opinion of supervisor teachers and teacher candidates about practicing activities. According to the research findings, being made suggestions directed to development of the teaching practice process.
\end{abstract} candidate

Key Words: Teaching practice, supervising teacher, teacher

\section{SUMMARY}

The aim of this study is to determine the views of the teacher candidates, who take the course "Teaching Practice" at the II. term of the $4^{\text {th }}$ class of the teacher training faculties for Elementary Education Level, about what duties and responsibilities the mentors, who work in the Elementary Education Schools, have to undertake at the time the teacher candidates are carrying out practice activities in the extent of this course and also to determine their

\footnotetext{
* Asist. Prof. Dr., Ankara University, Faculty of Educational Sciences

${ }^{* *}$ Ress. Assist., Ankara University, Faculty of Educational Sciences
} 
views about the activities of teaching practice. Again, in the extent of this study, it is also aimed to determine the views of the mentors, working in the Elementary Schools, about their own duties and responsibilities and their views about the activities of teaching practice. In the direction of this aim, the answers to the questions, given below, have been searched:

- What are the views of the teacher candidates, in the extent of the course "Teaching Practice", about the duties and the responsibilities that the mentors, in the Elementary Schools, have to undertake?

-What are the views of the teacher candidates about the activities which are done in the extent of teaching Practice?

-What are the views of the mentors, working in the Elementary Schools, which are in the extent of the course "Teaching Practice", about the duties and the responsibilities that the teacher candidates have to undertake?

-What are the views of the mentors, in the Elementary Schools, about the activities of teaching Practice?

-Is there a meaningful difference between the views of the mentors and the views of the teacher candidates about the duties and the responsibilities of the mentors?

This study is a kind of descriptive research. The last class students of the departments that train teachers for the Elementary Education Level (such as Departments of Teacher Education in Elementary Education and Teacher Education in Social Studies) in Ankara University Faculty of Educational Sciences and Gazi University Faculty of Education have formed the study group of the research. The teachers, working as mentors in the Elementary Schools, where the teacher candidates are sent to, have also formed the study group of this research. In the extent of this research, totally 341 teacher candidates from both universities and 80 mentors, working in the Elementary Schools, have been reached. The data, which are needed in the research, have been collected by the researchers with the help of two forms, which are developed separately for the mentors and the teacher candidates.

In one part of the applied form, the mentors and the teacher candidates have expressed their views through some given items. Frequency and percentage have been used in order to describe the datum, collected about each item. Moreover, "independent samples t-test" analysis has been used according to the total points obtained, in order to determine whether there is any meaningful difference between the average points which are obtained for the mentors and the teacher candidates, or not. And in the analysis of the answers, given to the open-ended items on the form, the common answers have been determined among the written answers of the mentors and the 
teacher candidates and these have been summarized, being gathered in an item.

According to the results that are gathered from the research, it has been deduced that; the cooperation among the teacher candidate, mentor and the teaching staff is not at enough level, the mentors do not support the teacher candidates in the process of developing lesson plans and materials, and there is a meaningful difference between the views of the mentors and the teacher candidates. Based upon the findings of the research, suggestions for developing the process of teaching practice have been made.

NOTE: This is an extended summary of the following article originally written in Turkish. 


\title{
Öğretmen Adaylarının ve İlköğretim Okullarında Görev Yapan Uygulama Öğretmenlerinin Öğretmenlik Uygulaması Etkinliklerine İlişkin Görüşleri
}

\author{
Erten GÖKÇE* Canay DEMIRHAN ${ }^{* *}$
}

ÖZ. $\mathrm{Bu}$ araştırmanın genel amacı, uygulama öğretmenleri ile öğretmen adaylarının ilköğretim okullarında gerçekleştirilen öğretmenlik uygulaması etkinliklerine ilişkin görüş ve önerilerini belirlemektir. Çalışma, betimsel türde bir araştırmadır. Araştırma verileri, 80 uygulama öğretmeninden ve 341 öğretmen adayından, 2003-2004 öğretim yılının II. yarıyılında, araştırmacılar tarafından geliştirilen anket formuyla toplanmıştır. Verilerin analizinde frekans ve yüzde kullanılmıştır. Araştırmadan elde edilen sonuçlara göre; öğretmen adayı, uygulama öğretmeni ve öğretim elemanı arasındaki işbirliğinin yeterli düzeyde olmadığı, uygulama öğretmenlerinin ders planları ve materyallerin geliştirilmesi sürecinde yeterince destek olmadıkları ve uygulama etkinliklerine ilişkin uygulama öğretmenleri ve öğretmen adaylarının görüşleri arasında anlamlı bir farklılık olduğu ortaya çıkmıştır. Araştırma bulgularına dayalı olarak, öğretmenlik uygulaması sürecinin geliştirilmesine yönelik önerilerde bulunulmuştur.

Anahtar Sözcükler: Öğretmenlik uygulaması, uygulama öğretmeni, öğretmen adayı

\section{GíRIŞ}

Öğretmen, bireyin nitelikli bir biçimde yetiştirilmesi sorumluluğunu taşımakla birlikte hızla değişen ve gelişen koşullar karşısında hizmet öncesi eğitimden başlamak üzere, sürekli kendisini geliştirmek durumundadır. Öğretmenlik mesleğinin gerektirdiği bilgi, beceri ve davranışlarla donatılmış bir öğretmen, gerçek okul ortamında uygulama etkinlikleriyle de çeşitli

${ }^{*}$ Yrd. Doç. Dr., Ankara Üniversitesi Eğitim Bilimleri Fakültesi

** Arş. Gör., Ankara Üniversitesi Eğitim Bilimleri Fakültesi 
deneyimler kazanmaktadır. Öğretmen adaylarının uygulama okullarında, uygulama öğretmenlerinin rehberliğinde kazandığı deneyimlerin yaşamda çok önemli bir yeri vardır. Okullardaki uygulama öğretmenleri, deneyimlerini öğretmen adaylarına yansıtabildikleri oranda verimli ve etkili olabilmektedir. $\mathrm{Bu}$ olgu, tarihsel süreç boyunca eğiticilerin yetiştirilmesinde çeşitli şekillerde ortaya çıkmıştır.

"Mentor" kavramı ilk kez, Homeros'un Odise adlı ünlü destanında Telemachus'u, babası Truva Savaşı'nda savaşırken, eğitmek ve desteklemek için seçilmiş karakterin adı olarak kullanılmıştır. Bu kavram bugün, akıllı ve güvenilir arkadaş anlamında kullanıldığı gibi öğretmen, destekleyici, rehber, koruyucu, himaye eden kavramlarını da içine alan bir role sahiptir(Villani 2002). Zachary (2000), bu kavramın kılavuz işlevini ön plana çıkararak, belirli bir zaman boyunca belirli bir konuda yeterli deneyimi olmayan kişilere tavsiyeler veren ve yardım eden deneyimli kişi olarak tanımlamıştır.

Öğretmen adaylarının hizmet öncesi eğitiminde de, uygulama öğretmenleri kılavuz olarak kabul edilmektedir. Hizmet öncesi öğretmen yetiştirme programında okul uygulamalarının en önemli işlevi, mesleğin tanıtılması ve bu doğrultuda katılımcı işbirliğiyle okullarda görevli uygulama öğretmenlerinin, öğretmen adaylarının mesleki gelişimine katkıda bulunabilmesidir. Buna göre, uygulama öğretmenleri ile öğretmen adaylarının rolleri farklıdır. Öğretmen adayı pasif alıcıdan, etkin bir ortağa ve işbirliği yapan kişiye dönüşmektedir. Öğrenme sürecinde, öğretmen adayının öğrenmesi için sorumlu olan ve öğretmen adayını yönlendiren k1lavuzdan, kendi kendini yönlendiren ve kendi ögrenmesinden sorumlu olan öğretmen adayına geçiş görülmektedir. Ayrıca uygulama öğretmeni ile öğretmen adayı arasındaki ilişkinin uzunluğu, takvime dayalı olmaktan belirlenen amaca dayalı olmaya doğru yönelmektedir(Kiraz 2002; Zachary 2000).

Öğretmen adayları, öğretmen olmak istedikleri için hizmet öncesi eğitim sürecine girerler ve bu eğitimde sadece nasıl öğreteceklerini öğrenmezler. Uygulama öğretmeni, öğretmen adaylarına tavsiyelerde bulunur; fakat bu, elbette, görevlerinden sadece biridir. Birçok çalışma, uygulama öğretmeni ile öğretmen adayı arasındaki ilişkiyi ele almıştır. Bu çalışmalar; öğretmen adaylarının okul sistemine, okul kültürüne uyumunun ve öğrenci öğrenmesini desteklemede etkililiğin artırılmasında uygulama öğretmeni-öğretmen adayı ilişkilerinin olumlu etkisini göstermiştir(Edwards and Collison 1996; Villani 2002).

Diğer yandan, uygulama öğretmenlerinde aranması gereken özelliklere bakıldığında bunların genelde gözardı edildiği görülmekte ve her öğretmen potansiyel uygulama öğretmeni olarak görülmektedir. Uygulama öğretmeni olabilmek için herhangi bir belirgin ölçüt olmadığı gibi, bu öğretmenlerin 
seçimi ya tamamen okul idaresine ya da üniversitedeki uygulama koordinatörüne bırakılmaktadır. Ancak bir öğretmen mesleğinde ne kadar yetkin olursa olsun, uygulama öğretmeni olabilmek için bazı ek becerilere sahip olması gerekmektedir (Kiraz 2002). Uygulama öğretmenlerinin istekli ve ilgili olmaları, öğretmenlik mesleğinin gerektirdiği yeterliklere üst düzeyde sahip olmaları ve kendilerini sürekli geliştiriyor olmaları öğretmen adaylarının nitelikli bir biçimde yetiştirilmesinde belirleyici bir rol oynamaktadır. $\mathrm{Bu}$ nedenle, uygulama öğretmenlerinin seçilmesini kolaylaştıracak objektif ölçütler geliştirilmelidir.

Uygulama öğretmenleri işbirliğine açı, öğretme-öğrenme süreçlerini tanıtmaya istekli ve paylaşımcı kişiler olmalıdır. Burada, uygulama öğretmenlerinden şu beceriler beklenmektedir: Uygulama öğretmeni, öğretmen adayı ile öğretmen adayına öğrenme hedeflerine ulaşmada kullanabileceği kaynaklara sahip olan ya da kaynakları sağlayan kişiler arasında doğru bağlantılar kurabilmeli ve bu ilişkileri sürdürebilmelidir(Zachary 2000). Bu beceriye yakın özellikler gösteren bazı unsurlar ise, Brooks ve Sikes (1997) tarafından şu şekilde sıralanmıştır:

- Okul, yerel topluluk ve okuldaki öğrenci sayısı hakkında öğretmen adaylarına bilgi sağlama (okul broşürü, personel el kitabı, zaman çizelgesi, çeşitli olayların takvimi, okul politikasıyla ilgili dokümanlar v.b.)

- Okuldaki düzenlemeler ve çeşitli etkinlikler hakkında öğretmen adaylarına bilgi verme

- Öğretmen adaylarına yönetim yapısını ve anahtar personel üyelerini tanıtma (öğretmen, müdür, müdür baş yardımcısı, bölüm başkanı, konu alanı uygulama ögretmenleri ve diğer destek personel gibi)

- Öğretmen adaylarına okul çevresinde rehberlik etme

- Öğretmen adaylarının dikkatini okulun sistemine, okul kurallarına, kullanılan ödül ve yaptırımlara çekme

- Uygun olarak öğretmen adaylarının mesleki katılım hakkında beklentilerinin taslağını, ana hatlarını hazırlama

- Öğretmen adaylarına okuldan yararlanabilecekleri, ulaşabilecekleri görsel/işitsel araç-gereçler ve bilgi teknolojisi kaynakları ile kayıt düzenlemeleri hakkında bilgi verme

Uygulama öğretmeni bu işlemleri gerçekleştirerek, öğretmen adayını hem ortama alıştırmış hem de çevresiyle etkileşim kurmasına yardım etmiş olur(Brooks and Sikes 1997).

Uygulama öğretmenleri; duygusal destek ve cesaret sağlayarak, okulun günlük çalışmaları ve kültürel normları hakkında bilgi sağlayarak, öğrenciler 
ve onların aileleri ile ilgili kültürel yeterliği destekleyerek ve bilişsel açıdan yönlendirip yetiştirerek öğretmen adaylarına destek olabilirler. Öğretmen adayları, tanıdık olmadıkları öğrencilerin kişilik özelikleri ve hazır bulunuşluk düzeyleri konusunda yardıma ihtiyaç duyabilirler. $\mathrm{Bu}$ tür durumlarda öğrenci davranışlarını yanlış yorumlayabilirler. Bu aşamada uygulama öğretmenleri, öğrencilerle iletișim kurma, onları anlama ve tanıma tekniklerini öğretmen adaylarına öğretmelidir. Öğretmen adayının sorular sorması kadar, sınıf gözlem verileri elde etmesi ve bunları paylaşarak kendini yansıtması, yansıtmayı teşvik eden başarılı bilişsel yönlendirmenin anahtar stratejileri durumundadır(Villani 2002).

Uygulama öğretmeni, öğretmen adayına nasıl bazı şeyleri daha etkili yapabileceğini öğretme yoluyla belirli bilgi aralıklarını doldurmasına yardım etmelidir. Öğretmen adayıyla etkili iletişim kurabilmelidir, öğretmen adayını destekleyen bir tutum içinde olmalıdır(Zachary 2000). Bu konuda, Edward ve Collins de (1996) uygulama öğretmenlerinin öğretmen adaylarını dinleme, genel sınıf yönetimi ve öğretimde model olma, öğretmen adayının ders uygulamasını analiz etme ve üzerinde tartışma, öğretmen adayını gözlemleme, öğretmen adayının kendi öğrenme amaçları üzerinde görüşme, öğretmen adaylarını öğretirken destekleme, sınıf olaylarına odaklanmış gözlemlerini cesaretlendirme gibi becerilere sahip olmaları gerektiğini belirtmişlerdir. Ayrıca uygulama öğretmeni, öğrenmeye olanak sağlamalı yani kolaylaştırıcı olmalıdır. Süreç içerisinde öğrenme amaçlarına ulaşılmasını sağlamalı, bir lider ve rehber olmalıdır.

Uygulama öğretmeni ile öğretmen adayı arasındaki işbirliğinde planlamanın özel bir yeri ve önemi vardır. Planlama süreci içerisinde; eğitim programı, sınıf içi öğrenme ürünleri, sınıftaki farklılıkları belirtme, görevler ve kaynaklar, öğretim zamanının kullanımı ve değerlendirme etkinlikleri yer alır. Bunlara bakarak, öğretmen adaylarının hizmet öncesi eğitimleri için fazla sayıda açıklanması gereken başlık olduğu söylenebilir. Diğer yandan planlamanın görev tasarım aşaması, öğretmen adaylarının öğrenen olarak öğrenci bakış açısından plan yapmaya başlama gereksinimini güçlendirir. Planlama içerisinde verilen her görev, öğretmen adaylarını önemli eğitimsel sorulara yönlendirir. Görev analizlerine bakılarak tüm soruların çözümüne başlanmalıdır. Öğretmen adaylarının öğrenme gereksiniminden başlayarak, planlama sürecinde öğrenci öğrenmeleri ile öğretmen adaylarının öğrenmeleri birlikte düşünülebilir: Öğretmen adaylarının öğrenme etkinliklerinin odak noktasını; beklenen öğrenme ürünlerini tanımlama, öğretmen adaylarının zaman kullanımını tartışma (ne zaman öğretecekler, ne zaman gözleyecekler) ve değerlendirme boyutları oluşturmaktadır(Edwards and Collison 1996).

Zachary'e (2000) göre, çalışma planını geliştirmek için uygulama öğretmeni ve öğretmen adayı şu yolu izlemelidir: Öğrenme amaçlarını 
tanımlama, amaçlara nasıl ulaşılacağını tanımlayan hedefleri ortaya koyma, olası kaynakları listeleme, hedef tarihi/bitiş tarihini belirleme. $\mathrm{Bu}$ olgu, uygulama öğretmeni ile öğretmen adayının eğitim amaçlarına ulaşma konusunda yoğun bir işbirliği yapmaları gerektiğini göstermektedir.

Uygulama öğretmeni, öğretmen adayıyla yapılan farklı bakış açıları hakkındaki konuşmaları yönetebilmeli, farklı bakış açılarını anlayabilmek için öğretmen adayıyla diyalog kurabilmelidir. Uygulama öğretmeni, öğretmen adayı için problemleri çözen kişi değil, problem çözme sürecinde ona yardım sağlayan kişi olmalıdır. Öğretmen adayına yapıcı dönüt vermeli ve ondan da dönüt almalıdır. Böylece değerlendirme ve birbiriyle bağlantılı öğrenmeler gerçekleştirilebilir ve gelecekteki öğrenmenin nasıl uygulamaya yansıtılacağı dikkate alınabilir. Uygulama öğretmeni öğretmen adaylarının kendi kendilerini değerlendirmelerini cesaretlendirmeli, öğretmen adaylarına yapıcı eleştiriler sağlamalı, öğretmen adaylarının uygulama etkinliklerinden öğrenebildiklerini onlara göstermelidir(Zachary 2000; Edwards and Collins 1996).

Brooks ve Sikes $(1997 ; 49)$ uygulama öğretmeninden değerlendirme aşamasında beklenen becerileri, aşağıdaki şekilde ifade etmiştir:

- Okuldaki başarıları hakkında tartışmak için öğretmen adaylarıyla buluşma

- Öğretmenlik mesleğinin gerektirdiği görev ve sorumlulukları her bir öğretmen adayı için koordine etme

- Uygulama sona ermeden önce mesleki başarının kayıtlarını kontrol etme; öğretmen adaylarının yaptıkları çalışmaları kabul etme ve onaylama

- Planlama sürecine bağlı olarak mesleki başarı kayıtlarını oluşturma, okulla ilgili raporları inceleme ve belirlenen hedefleri kontrol etme

- Formal olarak öğretmen adaylarını birçok durum içerisinde gözlemleme

- Öğretmen adaylarının başarıları ve öğretim yeterlikleri konusunda üniversitede öğretmenlik uygulamalarından sorumlu öğretim elemanı, konu alanı uygulama öğretmeni ve uygulama gözlemlerinde yer alan diğer ögretmenlerle danışmanlık yapma

- Öğretmen adaylarını, derste başarısızlıkla karşılaştıkları yerlerde uyarma ve üniversitede öğretmenlik uygulamasından sorumlu öğretim üyesine erken bir aşamada uyarıda bulunma derleme

- Her bir öğretmen adayının başarısı ve yeterliği üzerine bir rapor

- Raporu ilgili kişilere son teslim tarihinden önce gönderme 
Brooks ve Sikes (1997; 48), profesyonel bir uygulama öğretmeninin üstlenmesi gereken sorumlulukları ise, aşağıdaki başlıklar altında özetlemiştir:

\section{Uygulama Öğretmeninin Okul ve Üniversite Programına Katılımı}

- Üniversitedeki öğretim elemanı ile yapılandırılmış bir seri uygulamayı planlama. Örneğin çeşitli biçimlerde öğrenciyi izleme; farklı rollerdeki personeli izleme; bir grubun parçası olarak yalnızca bir dersin tümü ya da bir bölümü için bireysel, küçük grupla ve sinıflarla öğretim

- Dersin işleyişi üzerine işbirliği yapma ve üniversitedeki öğretim elemanı ile zamanı planlama

- Uygulamanın doğasının ve ders içerisindeki yerinin tam olarak farkına varma

- Okul ve öğretmenlerin gelişimi için çeşitli seminerler ve etkinlikler düzenleme ve mesleki gelişim çalışmalarını yürütme

- Dersi değerlendirmek için üniversitedeki öğretim elemanıyla çalışma ve mesleki gelişim etkinliklerine katılma

\section{Uygulama Öğretmeninin Grup Lideri Olarak Rol Alması}

- Uygulama öğretmenlerinin tüm okul gruplarını yönlendirmesi (örneğin planlamanın, gelişmenin, paylaşmanın, problem çözme ve gözlemlemenin amaçları için toplantılar düzenleme)

- Okul ve yerel toplum arasındaki işbirliği hakkında bilgi iletme (örneğin öğretmen adayları, meslektaşlar, destek personel, öğrenciler, devlet yetkilileri ve aileler)

- Dersteki, yönlendirmelere göre öğretmen adaylarının uygulamalarını gözlemleme

- Uygun olduğunda, üniversitedeki öğretim elemanlarının da katıldığ toplantılarda/görüşmelerde öğretmen adayı ile uygulama öğretmeni arasında ortaya çıkan problemler hakkında karar verme

- Biçimlendirici değerlendirme, ürün değerlendirme çalışmaları ile başarıyı kayıt etme sürecini koordine etme

- Her bir öğretmen adayının gelişimini koruma ve bir öğretmen adayı hakkında ciddi endişeler olduğu yerde, okul yöneticisine ve üniversitedeki ögretim elemanına bildirme

- Zor durumdaki öğretmen adayları için ek destekler organize etme

- Öğretmen adaylarının deneyimleri ile bağlantılı okul işlemlerini yeniden inceleme ve değerlendirme 
Sonuç olarak etkili bir uygulama öğretmeni, kendisini sürekli geliştiren, sınıf içi etkinlikleri öğrenci merkezli olarak organize edebilen, içeriğin seçimi ve düzenlenmesi konusunda yeterli bilgi ve beceriye sahip olan, değerlendirme ve geliştirme etkinliklerini başarılı bir biçimde uygulayabilen ve öğretmen adaylarıyla etkili iletişim kurabilen kişi olmalıdır.

Zachary (2000), uygulama öğretmenlerine öğretmen adaylarıyla olan ilişkileri için şu yönergeleri vermektedir: Öğretmen adayının soruları ile başlayın, öğretmen adayının amaçlarını tanımlayın, öğretmen adayının bilmek istediklerini belirleyin, amaçlara ulaşmak için alternatif yaklaşımlar sunun, açık olan ve olmayan durumları sorun, olası seçenekler sağlayın, benzer diğer durumlar hakkında bilgi verin, öğretmen adayına problemin çözümünü sağlamadan önce, problem çözme sürecinde yardım ederek, onu düşünmeye ve eylemde bulunmaya yönlendirin, davranışa yönlendirmeden önce seçeneklerin keşfedilmesini destekleyin, yargılarınızı erteleyin, empatik olun, uygun olarak dönüt sağlayın, şefkat gösterme ile zorlama arasında denge kurun, sorular sorun, karmaşıklıkların basit olabileceğini hatırlatın, doğru soru sormanın zamanını bilin ve "yapabilirsin" mesajını verin, yaptıklarınızı ve neden yaptığınızı söyleyin, olası stratejiler yoluyla konuşun, ortak firsatlar yaratın.

Tüm bu olgular uygulama öğretmenlerinin üstlendikleri görev ve sorumlulukların nitelikli öğretmenlerin yetiştirilmesinde ve çok yönlü deneyimler kazanmalarında belirleyici bir etkiye sahip olduklarını açıkça göstermektedir. Uygulama öğretmenleri rollerini tam olarak gerçekleştirdikleri zaman, işlerini nitelikli bir şekilde yapabileceklerdir (Villani 2002; Zachary 2000).

Hizmet öncesi eğitim sürecinde, uygulama öğretmenleri ile öğretmen adayları arasındaki iletişime özellikle önem verilmektedir. Hazırlama, tartışma (görüşme), imkan verme ve kapanış öğelerinin her uygulama öğretmeni-öğretmen adayı ilişkisinde yer alması gerekir. Hazırlama unsuru, bir keşif sürecidir. Uygulama öğretmeni, bu aşamada beklenen uygulama öğretmeni-öğretmen adayı ilişkisinin durumunu değerlendirir. Öğretmen adayıyla yapılan ilk konuşma ilişkinin uyumunu, genel havasını hazırlar. Yapılan görüşmeler sonucunda, öğrenme amaçları üzerinde anlaşmaya varılır ve hangi etkinliklerin nasıl gerçekleştirileceği belirlenir.

Brooks ve Sikes (1997) tarafından uygulama öğretmenlerinin mesleki yeterlikleri dışında sahip olmaları gereken kişisel özelliklerin de önemli olduğu belirtilmiştir. Bu kişisel özellikler aşağıda verilmiştir:

- Öğretim konusunda gayretli olmaları

- Kendi uygulamalarını yansıtmaya istekli olmaları 

olmaları

- Öğrencilerle kendi uygulamalarını eleştirel olarak incelemeye hazır

- Öğrenme ve öğretme yaklaşımlarına bakış ile açık fikirli olmaları olmaları

- Öğretim ve öğrenmede beceri ve anlayışın gelişmesine istekli

- Öğrencilere sempatik ve anlayışlı bir yaklaşımla ulaşmaları

- Olumlu ve cesaret veren bir tutuma sahip olmaları

- Destekleyici olmaları

- Yapılandırmacı bir biçimde eleştirel olmaları

- Etkili bir iletişim kurma ve dinleme becerisine sahip olmaları

Öğretmen adayı, uygulama öğretmeninden yalnızca bilgi, beceri ve davranış kazanmanın yanı sıra, onun kişilik özelliklerinden de etkilenmekte, hatta onu model olarak alabilmektedir. Bu nedenle, uygulama öğretmeniyle öğretmen adayı arasındaki etkileşim ve işbirliğinin güçlü olması gerekir. Kuşkusuz öğretmen adaylarının da uygulama öğretmenlerinden çeşitli beklentileri vardır. Brooks ve Sikes (1997) bu beklentileri aşağıdaki gibi özetlemişlerdir:

- Neyin, nasıl öğretileceği ve bir öğretmen olarak nasıl davranılacağı hakkında açık fikirli olarak düşünme

- Sınıf yönetimi ve organizasyonu konularında yeterli olma

- Eğitim programı temelli planlama ve geliştirme etkinlikleri hazırlama

- Öğrenciler için içerik ve öğretim stilleri seçme

- Başarı ve uyum sorunu yaşayan öğrencilerle ilgilenme

- Dersi işlemede pratik stratejiler kullanma

- Bir şeyler yanlış gittiğinde bunlarla başa çıkma ve bunları yönetme yolların bilme

- Notlandirma ve değerlendirme ile kayıt tutmada ve rapor yazma tekniklerinde yeterli olma

- Uygulamalı çalışmalar planlama ve yönetme

- Meslektaşlarıyla işbirliği içerisinde çalışma

- Öğretmenlik uygulamaları hakkında tavsiyeler verme

Öğretmen adaylarının uygulama öğretmenlerinden beklentilerine karşılık olarak uygulama öğretmenleri de öğretmen adaylarının kendilerine özgü öğretim modelleri geliştirmelerine yardımcı olmalı, onlara rehberlik 
etmeli ve öğretmen adaylarının karşılaştıkları sorunlarda kendi çözüm yollarını ortaya koyma sorumluluğuna sahip olmaları gerekir. Temel olarak öğretmenlik uygulaması dersinin amaçları arasında bu olgular ayrıntılı bir biçimde yer almaktadır. Öğretmenlik uygulaması dersinin temel amacı, öğretmen adayının gerçek öğretim ortamında öğretme-öğrenme sürecine aktif bir biçimde katılarak, öğreticilik bilgi ve becerisi kazanmasını sağlamaktır. $\mathrm{Bu}$ amacın gerçekleştirilebilmesi büyük ölçüde üniversite, uygulama öğretmeni ve öğretmen adayı arasındaki işbirliğine bağlıdır.

Öğretmenlik uygulaması dersinin amaçlarının gerçekleştirilebilmesi, uygulama öğretmenleri ile öğretmen adaylarının bu kapsamda gerçekleştirilen tüm etkinliklere ilişkin görüş ve önerilerinin belirlenmesiyle sağlanabilir. Ayrıca ülkenin ihtiyaç duyduğu nitelikli öğretmenlerin yetiştirilebilmesi sürecinde öğretmenlik uygulamalarının özel bir yeri vardır. Çünkü öğretmen adayı bu etkinlikler kapsamında gerçek sınıf ortamında öğretici rol ve sorumluluğunu üstlenebilmektedir. $\mathrm{Bu}$ nedenle, uygulama öğretmenlerinin ve öğretmen adaylarının öğretmenlik uygulaması sürecine ilişkin görüş ve önerilerinin alınması önemli ve gerekli görülmüştür. Yapılan bu çalışma ile öğretmenlik uygulaması sürecinin geliştirilebilmesi ve hedeflenen verimliliğe ulaşabilmesi mümkün olabilecektir.

\section{Amaç}

$\mathrm{Bu}$ çalışmanın amac1, İlköğretim kademesine öğretmen yetiştiren fakültelerin 4. sınıfının II. döneminde "Öğretmenlik Uygulaması" dersini alan öğretmen adaylarının, bu ders kapsamında yürüttükleri uygulama etkinlikleri sırasında, ilköğretim okullarında görev yapan uygulama öğretmenlerinin üstlenmesi gereken görev ve sorumluluklar ile öğretmenlik uygulaması etkinliklerine ilişkin görüşlerini belirlemektir. Yine bu çalışma kapsamında, ilköğretim okullarında görev yapan uygulama öğretmenlerinin kendi görev ve sorumlulukları ile öğretmenlik uygulaması etkinliklerine ilişkin görüşlerinin de saptanması amaçlanmıştır.

$\mathrm{Bu}$ genel amaç doğrultusunda, aşağıda belirtilen sorulara yanıt aranmıştır:

- Öğretmen adaylarının "Öğretmenlik Uygulaması" dersi kapsamında, ilköğretim okullarındaki uygulama öğretmenlerinin üstlenmesi gereken görev ve sorumluluklara ilişkin görüşleri nelerdir?

- Öğretmen adaylarının, ögrretmenlik uygulaması kapsamında gerçekleştirilen etkinliklere ilişkin görüşleri nelerdir?

- "Öğretmenlik Uygulaması" dersi kapsamında ilköğretim okullarındaki uygulama ögretmenlerinin, ögretmen adayları için üstlenmesi gereken görev ve sorumluluklarına ilişkin görüşleri nelerdir? 
- İlköğretim okullarındaki uygulama ögrretmenlerinin, ögretmenlik uygulaması etkinliklerine ilişkin görüşleri nelerdir?

- Uygulama öğretmenlerinin görev ve sorumluluklarına ilişkin uygulama ögretmenleri ile öğretmen adaylarının görüşleri arasında anlamlı bir fark var midır?

\section{YÖNTEM}

İlköğretim okullarında görev yapan uygulama öğretmenlerinin ve öğretmen adaylarının, öğretmenlik uygulaması etkinliklerine ilişkin görüşlerini belirlemeye yönelik olarak yapılan bu çalışma, betimsel türde bir araştırmadır. $\mathrm{Bu}$ araştırma kapsamında, öğretmen adaylarına öğretmenlik mesleğinin uygulanışı konusunda rehberlik yapan uygulama öğretmenlerinin görüş ve önerileri ile öğretmen adayı öğrencilerin görüş ve önerileri ortaya konmuştur. Ayrıca öğretmen eğitimi ve okullarda uygulama etkinlikleri ile ilgili alanyazın da incelenmiştir.

\section{Araştırma Grubu}

Araştırmanın çalışma grubunu, Ankara Üniversitesi Eğitim Bilimleri Fakültesi ve Gazi Üniversitesi Eğitim Fakültesi'nde ilköğretim kademesine öğretmen yetiştiren bölümlerin (Sınıf Öğretmenliği, Sosyal Bilgiler Öğretmenliği) son sınıf öğrencileri oluşturmaktadır. Aynı fakültelerin öğretmen adaylarını gönderdikleri ilköğretim kurumlarında uygulama öğretmeni olarak görev yapan öğretmenler de bu araştırmanın çalışma grubunu oluş̧urmuştur. $\mathrm{Bu}$ araştırma kapsamında, her iki üniversiteden toplam 341 ögretmen adayına ve ilköğretim okullarında görev yapan 80 uygulama öğretmenine ulaşılmıștır. Çalıșma grubundaki uygulama öğretmenleri belirlenirken, 2003-2004 öğretim yılında öğretmen adaylarına rehberlik yapıyor olmaları dikkate alınmıştır.

\section{Veri Toplama Aracı ve Verilerin Toplanması}

Araştırmada ihtiyaç duyulan veriler, uygulama öğretmenleri ve öğretmen adayları için ayrı ayrı geliştirilen iki anket formuyla araştırmacılar tarafından toplanmıştır. Uygulama öğretmenleri için hazırlanan anket formu 3'ü açık uçlu olmak üzere, toplam 27 maddeden oluşmuştur. Öğretmen adayları için hazırlanan anket formu ise, 3'ü açık uçlu olmak üzere, toplam 25 maddeden oluşmuştur. Öğretmen adayları için geliştirilen anket formundaki 22 madde ile uygulama öğretmenleri için hazırlanan anket formundaki 22 madde birbirlerine paralel biçimde hazırlanmış, anket formuna son şekli verilmeden önce ilköğretim bölümlerinde öğretmenlik uygulamaları konusunda çalışan ya da uygulama etkinliklerine katılan uzmanlardan görüş alınmıştır. Veri toplama aracında beşli derecelendirme kullanılmıştır. Araştırma için ihtiyaç duyulan veriler, Nisan - Mayıs 2004 tarihlerinde toplanmıştır. 


\section{Verilerin Analizi}

Uygulama öğretmenlerinden ve öğretmen adaylarından toplanan veriler, araştırmacılar tarafindan incelenerek analiz edilmiştir. Yapılan analizler doğrultusunda, uygulama öğretmeni ve öğretmen adaylarının görüșleri, her bir maddeye ait toplanan verilerin betimlenmesi amaciyla, frekans ve yüzde kullanılarak iki ayrı tablo halinde gösterilmiştir. Ayrıca uygulama öğretmenlerinin ve ögretmen adaylarının anketlerinde yer alan 22 maddeden toplam puanlar elde edilmiştir. Toplam puanlar elde edilirken ankette yer alan her bir derece puanlanmıştır(Her zaman $=5$ puan, Çoğu zaman $=4$ puan, Bazen $=3$ puan, Nadiren $=2$ puan, Hiçbir zaman $=1$ puan). Uygulama öğretmenleri ve öğretmen adayları için elde edilen ortalama puanları arasında anlamlı bir farklılık olup olmadığını belirlemek için "iliş̧isiz örneklemler için t-testi” analizi kullanılmıştır. Bu iki grubun görüşleri bir tabloda, "ilişkisiz örneklemler için t-testi" kullanılarak karşılaştırılmıştır. Açık uçlu soruların analizinde ise, uygulama öğretmenlerinin ve öğretmen adaylarının yazılı olarak verdikleri yanitlardan, ortak olan yanitlar belirlenmiş ve bunlar bir maddede toplanarak özetlenmiştir.

\section{BULGULAR VE YORUM}

$\mathrm{Bu}$ bölümde, uygulama öğretmenlerinden ve öğretmen adaylarından elde edilen görüş̧ler doğrultusunda oluşturulan bulgular ve yorumlara yer verilmiştir. Tablo 1'de öğretmen adaylarının görüşleri, Tablo 2'de uygulama öğretmenlerinin görüşleri verilmiştir. Uygulama öğretmenleri ve öğretmen adaylarından elde edilen görüşlerin genel olarak betimlenmesi amacıyla frekans ve yüzde kullanılmıştır. Tablo 3 'te ise bu uygulama öğretmenleri ile öğretmen adaylarının görüşleri karşılaştırılmıştır. 
Tablo 1: Uygulama Öğretmenlerinin Görev ve Sorumluluklarına İlişkin Öğretmen Adaylarının Görüşleri

\begin{tabular}{|c|c|c|c|c|c|c|c|c|c|c|c|c|}
\hline \multirow[t]{2}{*}{ Maddeler } & \multicolumn{2}{|c|}{ Her zaman } & \multicolumn{2}{|c|}{$\begin{array}{l}\text { Çoğu } \\
\text { zaman }\end{array}$} & \multicolumn{2}{|c|}{ Bazen } & \multicolumn{2}{|c|}{ Nadiren } & \multicolumn{2}{|c|}{$\begin{array}{l}\text { Hiçbir } \\
\text { zaman }\end{array}$} & \multirow[b]{2}{*}{ Boş } & \multirow[b]{2}{*}{ Toplam } \\
\hline & (f) & $(\%)$ & (f) & (\%) & (f) & (\%) & (f) & $(\%)$ & (f) & $(\%)$ & & \\
\hline $\begin{array}{l}\text { Uygulama öğretmeni, uygulamadan sorumlu öğretim } \\
\text { elemanı ile işbirliği içerisinde çalışır. }\end{array}$ & 81 & 24,2 & 109 & 32,5 & 66 & 19,7 & 53 & 15,8 & 26 & 7,8 & 6 & 335 \\
\hline $\begin{array}{l}\text { Uygulama öğretmeni sınıftaki öğrencilerle bizi } \\
\text { tanıştırarak etkileşim kurmamızı sağlar. }\end{array}$ & 95 & 27,9 & 123 & 36,1 & 62 & 18,2 & 36 & 10,5 & 25 & 7,3 & - & 341 \\
\hline $\begin{array}{l}\text { Uygulama öğretmeni öğrencilerin hazırbulunuşluk } \\
\text { düzeyleri, ilgi ve yetenekleri hakkında bize bilgi } \\
\text { verir. }\end{array}$ & 88 & 25,9 & 85 & 25,1 & 84 & 24,8 & 48 & 14,2 & 34 & 10,0 & 2 & 339 \\
\hline $\begin{array}{l}\text { Uygulama öğretmeni okuldaki diğer öğretmen ve } \\
\text { yöneticilerle bizi tanıştırır. }\end{array}$ & 55 & 16,2 & 50 & 14,8 & 77 & 22,7 & 65 & 19,2 & 92 & 27,1 & 2 & 339 \\
\hline $\begin{array}{l}\text { Uygulama öğretmeni okulu (kütüphane, laboratuar, } \\
\text { atölye, spor salonu vb.) tanıtır. }\end{array}$ & 42 & 12,5 & 44 & 13,1 & 60 & 17,8 & 63 & 18,7 & 128 & 37,9 & 4 & 337 \\
\hline Uygulama öğretmeni uygulamaya başlamadan önce & & & & & & & & & & & & \\
\hline $\begin{array}{l}\text { kendisini izleyerek bilgi ve deneyim kazanmamızı } \\
\text { sağlar. }\end{array}$ & 125 & 36,6 & 107 & 31,4 & 50 & 14,7 & 27 & 7,9 & 32 & 9,4 & - & 341 \\
\hline $\begin{array}{l}\text { Uygulama öğretmeni her bir dersin çalışma planı } \\
\text { hakkında bize ayrıntılı bilgi verir. }\end{array}$ & 44 & 12,9 & 80 & 23,5 & 81 & 23,8 & 74 & 21,8 & 61 & 18 & 1 & 340 \\
\hline $\begin{array}{l}\text { Uygulama öğretmeni sınıf içi etkinlikleri } \\
\text { hazırlamamızda yardımcı olur. }\end{array}$ & 49 & 14,5 & 103 & 30,6 & 74 & 22 & 54 & 16 & 57 & 16,9 & 4 & 337 \\
\hline $\begin{array}{l}\text { Uygulama öğretmeni, ders planlarını hazırlamamız } \\
\text { sürecinde bizimle etkilesim icinde calısır. }\end{array}$ & 59 & 17,5 & 77 & 22,8 & 84 & 24,8 & 60 & 17,8 & 58 & 17,1 & 3 & 338 \\
\hline
\end{tabular}


Uygulama öğretmeni, gerek duyduğumuzda, öğretim ilke, yöntem ve teknikleri hakkında bize açıklamalar yapar.

Uygulama öğretmeni ders sunumu için gerekli olan ders araç-gereçlerini ve kaynaklarını edinmemizde yardımci olur.

Uygulama öğretmeni ders işleyişimizle ilgili bizden beklediği davranışları söyler.

\begin{tabular}{rrrrrrrrrrrr}
65 & 19,2 & 105 & 31 & 75 & 22,1 & 56 & 16,5 & 38 & 11,2 & 2 & 339 \\
81 & 24 & 111 & 33 & 71 & 21 & 45 & 13,4 & 29 & 8,6 & 4 & 337 \\
90 & 26,4 & 108 & 31,7 & 87 & 25,5 & 37 & 10,8 & 19 & 5,6 & - & 341 \\
70 & 20,7 & 104 & 30,7 & 91 & 26,8 & 53 & 15,6 & 21 & 6,2 & 2 & 339 \\
84 & 24,6 & 91 & 26,7 & 84 & 24,6 & 54 & 15,9 & 28 & 8,2 & - & 341 \\
49 & 14,5 & 103 & 30,4 & 97 & 28,6 & 52 & 15,3 & 38 & 11,2 & 2 & 339 \\
115 & 34 & 113 & 33,3 & 57 & 16,8 & 35 & 10,3 & 19 & 5,6 & 2 & 339 \\
121 & 36,3 & 106 & 31,8 & 75 & 22,5 & 18 & 5,4 & 13 & 4 & 8 & 333 \\
99 & 29,4 & 123 & 36,5 & 72 & 21,4 & 21 & 6,2 & 22 & 6,5 & 4 & 337 \\
61 & 18,3 & 97 & 29 & 84 & 25,1 & 53 & 15,9 & 39 & 11,7 & 7 & 334 \\
87 & 25,7 & 108 & 32,0 & 82 & 24,3 & 34 & 10,0 & 27 & 8,0 & 3 & 338 \\
65 & 19,6 & 88 & 26,6 & 79 & 23,9 & 54 & 16,3 & 45 & 13,6 & 10 & 331 \\
95 & 28,0 & 83 & 24,5 & 81 & 23,9 & 42 & 12,4 & 38 & 11,2 & 2 & 339 \\
\hline
\end{tabular}

Uygulama öğretmeni sınıf yönetimi teknikleri

hakkında bize ipuçları verir.

Uygulama öğretmeni hazırladığımız ders planlarını

ve araçlarını kontrol eder.

Uygulama öğretmeni işlemeyi planladığımız dersle

ilgili bize örnek etkinlikler gösterir.

Uygulama öğretmeni bizi destekleyici ve

cesaretlendirici tutum ve davranışlar gösterir.

Uygulama öğretmeni ders işlerken bizi gözlemler.

Uygulama öğretmeni sınıf içi etkinliklerimizi değerlendirir.

Uygulama öğretmeni işlediğimiz dersle ilgili bize

pekiştireçler verir.

Uygulama öğretmeni işlediğimiz dersle ilgili olarak

yapıcı eleştirilerde bulunur.

Uygulama öğretmeni değerlendirme sonuçlar

hakkında bizi bilgilendirir.

Uygulama öğretmeni kişilik özellikleri, tutum ve davranışları ile bizim için nitelikli bir modeldir. 
Genel olarak Tablo 1'deki veriler incelendiğinde, öğretmen adaylarının yaklaşık üçte biri $(\% 36,6)$, uygulama yapmadan önce her zaman, uygulama öğretmenlerinin kendilerini izleyerek bilgi ve deneyim kazanmalarını sağladığını belirtmiştir. Ayrıca yine öğretmen adaylarının yaklaşık üçte biri, uygulama öğretmenlerinin çoğu zaman sınıftaki öğrencileri kendileriyle tanıştırarak etkileşim kurulmasını sağladığını $(\% 36,1)$, öğretmen adayları tarafindan gerçekleştirilen sınıf içi etkinliklerin uygulama öğretmenleri tarafindan değerlendirildiğini $(\% 36,5)$ ve uygulama öğretmenlerinin her zaman öğretmen adayları ders işlerken onları gözlemlediğini $(\% 36,3)$ ifade etmiştir. Öğretmen adaylarının yine yaklaşı üç̧e biri, uygulama öğretmenlerinin hiçbir zaman okulu $(\% 37,9)$, diğer öğretmenleri ve yöneticileri kendilerine tanıtmadığını $(\% 27,1)$ ifade etmişlerdir. Ayrıca öğretmen adaylarının sadece \%28'i her zaman, \%24,5'i çoğu zaman, uygulama öğretmelerini nitelikli bir model olarak gördüğünü belirtmiştir.

Öğretmen adaylarından elde edilen bulgular doğrultusunda adayların cevapları, uygulama öğretmenlerinin öğretmen adaylarına, öğrencilerin hazır bulunuşluk düzeyleri, ilgi ve yetenekleri konusunda bilgi verme, ders planı hakkında bilgi verme, ders planının hazırlanmasında öğretmen adayıyla etkileşimde bulunma, öğretmen adayının hazırladığı ders planını ve araçgereçleri kontrol etme, öğretmen adayına pekiştireçler verme, değerlendirme sonuçları hakkında bilgi verme konularında beşli derecelendirmenin farklı düzeylerinde düşük yüzdelere sahip oldukları belirlenmiştir. Kiraz (2002) ile Talvitie, Peltokallio ve Mannisto'nun (2000) araştırmalarında da öğretmen adayları, uygulama öğretmenlerinin kendilerine özellikle ders planları ve materyallerle ilgili olarak rehber olmalarında ve uygulama öğretmenleriyle bu konuda etkileşime girmelerinde sorun yaşandığını belirtmişlerdir.

Öğretmenlik uygulaması etkinliklerinin en önemli parçası olan ders planları ve materyallerinin hazırlanması konusunda, öğretmen adaylarının uygulama öğretmenlerinin yönlendirmelerine ve rehberliğine ihtiyaçları vardır. Ancak elde edilen bulgulara göre, bu rehberliğin uygulama öğretmenleri tarafından tam olarak sağlanamadığ 1 görülmektedir. Öğretmeöğrenme sürecinin niteliği, büyük ölçüde öğretmenin performansına bağlıdır. $\mathrm{Bu}$ da, öğretmenin gerekli ön hazırlıkları yapması, kaynak ve dokümanları hazırlaması ve etkili sunuş stratejileri belirlemesi anlamına gelmektedir. Uygulama ögrretmenlerinin bu konuya gereken duyarlılığı göstermeleri ve paylaşımcı bir nitelik taşımaları, sürecin verimliliği açısından son derece önem taşımaktadır. 

Ankara University, Journal of Faculty of Educational Sciences, year: 2005, vol: 38, no: 1, 43-71

Tablo 2: Uygulama Öğretmenlerinin Görev ve Sorumluluklarına İlişkin Öğretmenlerin Görüşleri

Maddeler

Ögretmen adaylarının eğitiminde, uygulamadan

sorumlu öğretim elemanı ile işbirliği içerisinde 26 çalışırım.

Öğretmen adaylarını sınıftaki öğrencilerle 57 tanıştırarak etkileşim kurmalarını sağlarım.

Öğretmen adaylarına öğrencilerin hazırbulunuşluk

düzeyleri, ilgi ve yetenekleri hakkında bilgi veririm.

Öğretmen adaylarını okuldaki diğer öğretmen ve 30

yöneticilerle tanıştırırım.

Öğretmen adaylarına okulu (kütüphane, laboratuar,

atölye, spor salonu vb.) tanıtırım.

Öğretmen adaylarının uygulamaya başlamadan önce

beni izleyerek bilgi ve deneyim kazanmalarını 56

sağlarım.

Öğretmen adaylarına her bir dersin çalıșma planı

hakkında ayrıntılı bilgi veririm.

Öğretmen adaylarının sınıf içi etkinlikleri
hazırlamalarına yardımcı olurum.

hazırlamalarına yardımcı olurum.

Öğretmen adaylarının ders planlarını hazırlamaları

sürecinde onlarla etkileșim içinde çalıșırım.

Öğretmen adaylarına (gerektiğinde) öğretim ilke,

yöntem ve teknikleri hakkında açıklamalar yaparım.

\section{Her zaman}

Çoğu

Bazen

Nadiren

Hiçbir

zaman

$\begin{array}{llllllllll}\text { (f) } & (\%) & \text { (f) } & (\%) & \text { (f) } & \text { (\%) } & \text { (f) } & \text { (\%) } & \text { (f) } & \text { (\%) }\end{array}$

$\begin{array}{rrrrrrrrrrr}32,9 & 25 & 31,6 & 9 & 11,4 & 6 & 7,6 & 13 & 16,5 & 1 & 79 \\ 71,3 & 21 & 26,2 & 2 & 2,5 & & & & & - & 80 \\ 51,3 & 31 & 38,8 & 7 & 8,7 & 1 & 1,2 & & & - & 80 \\ 37,5 & 30 & 37,5 & 17 & 21,3 & 2 & 2,5 & 1 & 1,2 & - & 80 \\ 31,3 & 34 & 42,5 & 16 & 20,0 & 3 & 3,7 & 2 & 2,5 & - & 80\end{array}$

$70,9 \quad 21$

$53,8 \quad 31$

$44,3 \quad 3$

$\begin{array}{lll}26,6 & 2 & 2,5\end{array}$

38,8

$6,2 \quad 1$

1,2

80

$43,8 \quad 32$

$40,0 \quad 1$

13,8

$50,0 \quad 30$

37,5

$11,3 \quad 1$ 
Öğretmen adaylarına ders sunumu için gerekli olan ders araç-gereçlerini ve kaynaklarını edinmelerinde yardımci olurum.

Öğretmen adaylarının ders işleyişleri ile ilgili

kendilerinden beklediğim davranısları söyleri

Öğretmen adaylarına sınıf yönetimi teknikleri 40

hakkında ipuçları veririm.

Öğretmen adaylarının ders planlarını ve araçlarını

kontrol ederim.

Öğretmen adaylarına işlemeyi planladıkları dersle 33

ilgili örnek etkinlikler gösteririm.

Öğretmen adaylarını destekleyici ve cesaretlendirici tutum ve davranışlar gösteririm.

Öğretmen adaylarını ders işlerken gözlemlerim.

Öğretmen adayının sınıf içi etkinliklerini değerlendiririm.

Öğretmen adaylarına işledikleri dersle ilgili 39

pekiștireçler veririm.

Öğretmen adaylarına işledikleri dersle ilgili olarak yapıcı eleştirilerde bulunurum.

Öğretmen adaylarının çalışmaları ile ilgili 38

değerlendirme raporu hazırlarım.

Değerlendirmelerimin sonuçları hakkında öğretmen

adaylarını bilgilendiririm.

Ögrretmen adaylarıla ilgili raporumu uygulama 52

koordinatörüne teslim ederim/gönderirim.

Öğretmen adaylarına kişilik özelliklerim, tutum ve

davranışlarım ile nitelikli bir model olmaya çalışırım.
$60,0 \quad 29$

$46,3 \quad 27$

$50,6 \quad 26$

$54,4 \quad 17$

$41,8 \quad 32$

$73,4 \quad 21$

$77,2 \quad 18$

$66,7 \quad 21$

$50 \quad 32$

$53,2 \quad 27$

$49,3 \quad 29$

$48,1 \quad 23$

$66,7 \quad 23$

$68,4 \quad 23$
$36,3 \quad 3$

3,7

80

$33,7 \quad 14 \quad 17,5 \quad 2$

$\begin{array}{lllll}33 & 11 & 13,9 & 2 & 2,5\end{array}$

$21,5 \quad 15$

$40,5 \quad 11$

193

26,6

22,8

$26,9 \quad 5$

417

$34,2 \quad 10 \quad 12,6$

$\begin{array}{lllll}37,7 & 9 & 11,7 & 1 & 1,3\end{array}$

$29,1 \quad 13 \quad 16,5 \quad 5 \quad 6,3$

$29,5 \quad 3 \quad 3,8$

$29,1 \quad 2 \quad 2,5$ 
Tablo 2'deki bulgular genel olarak incelendiğinde, uygulama öğretmenlerinin yarıdan fazlasının her zaman özellikle öğretmen adaylarını ders işlerken gözlemlediklerini, onlara karşı destekleyici, cesaretlendirici tutum ve davranışlar gösterdiklerini, adayları ögrencileriyle tanıştırdıklarını ve adayların kendilerini izlemelerini sağladıklarını belirtmişlerdir. Uygulama öğretmenlerinin yarıdan fazlası, öğretmenlik uygulaması etkinliklerinde kendilerinden beklenen görev ve sorumlulukları her zaman ya da çoğu zaman gerçekleştirdiklerini ifade etmişlerdir. Diğer yandan uygulamadan sorumlu öğretim elemanı ile işbirliği içerisinde çalışma, uygulama öğretmenlerinin her zaman gerçekleştirdiklerini ifade ettikleri görev ve sorumluluklardan en az yüzde değere $(\% 32,9)$ sahip olan madde olmuştur.

Uygulama öğretmenlerinin cevaplandırdığı anket formundaki maddelere ait yüzde değerlerinin, uygulama etkinlikleri ile ilgili görev ve sorumlulukları gerçekleştirme yönünde, öğretmen adaylarının anket maddelerine ait yüzde değerlere göre daha yüksek olduğu görülmektedir. Bu olgu, uygulama öğretmenlerinin kendilerini objektif bir biçimde değerlendirmede güçlük yaşadıklarını düşündürmektedir. Jones, Reid ve Bevins (1997), tarafından yapılan araştırmada da öğretmenlik ile uygulama öğretmenliğinin birbirinden farklı olduğu ifade edilmiş ve öğretmenlerden, uygulama öğretmenlerinin görev ve sorumluluklarının neler olması gerektiği hakkında bilgi alınmıştır. Yapılan bu çalışmada, uygulama öğretmenleri, beklenen görev ve sorumlulukları gösterdiklerini ifade etmişlerdir; ancak bu olgu, öğretmen adayları tarafindan doğrulanmamıştır. Uygulama öğretmenleri ile öğretmen adaylarının öğretmenlik uygulaması sürecine ilişkin görüşlerinin farklı olması, bu konuda işbirliği ve etkileşimin geliştirilmesi ve bu olgunun sorgulanması gerektiğini açıkça göstermektedir.

Tablo 3: Uygulama Öğretmenleri ve Öğretmen Adaylarının Görüşlerine İlişkin İlişkisiz Örneklemler İçin t-Testi Sonuçları

\begin{tabular}{lllllll}
\hline Gruplar & $\mathbf{N}$ & $\bar{X}$ & $\mathbf{S}$ & $\mathbf{t}$ & $\mathbf{s d}$ & $\mathbf{p}$ \\
\hline Uygulama öğretmeni & 80 & 95,2125 & 10,71341 & 9,586 & 419 &, 000 \\
Öğretmen Adayı & 341 & 73,4545 & 19,61396 & & & \\
\hline
\end{tabular}

Tablo 3'teki bulgular incelendiğinde, uygulama öğretmenlerinin ve öğretmen adaylarının cevapladığı anketlerden ayrı ayrı ortalama puanlar elde edilmiştir. Uygulama öğretmenleri ve öğretmen adaylarının anketlerinden 
elde edilen ortalama puanlar arasında anlamlı bir farklılık olup olmadığını belirlemek için "iliş̧kisiz örneklemler için t-testi" analizi kullanılmıştır. Anketlerden elde edilen ortalama puanlarına göre, uygulama öğretmenleri ile öğretmen adayları arasında uygulama öğretmenleri lehine anlamlı bir fark gözlenmiştir[ $\left.\mathrm{t}_{(419)}=9,586, \mathrm{p}<.01\right]$. Her bir madde için ayrı ayrı ortalama puanlara bakıldığında da, 1 . madde dışında tüm maddelerin ortalama puanına göre uygulama öğretmenleri ve öğretmen adayları arasında, uygulama ögretmenleri lehine anlamlı bir fark gözlenmektedir.

Uygulama öğretmenleri ile öğretmen adayları arasındaki bu farkın, uygulama öğretmenlerinin üstlendikleri görev ve sorumluluklar konusunda, kendilerini daha olumlu değerlendirmelerinden kaynaklandiğı düşünülmektedir. Ünver ve Erdoğan'ın araştırmasında da (2003) uygulama öğretmenleri ile öğretmen adaylarının görüşleri arasında anlamlı bir ilişki bulunamadığı belirtilmiştir. Oysa uygulama öğretmeni ve öğretmen adayı ortak bir amaç çerçevesinde bir araya gelmekte ve birbirlerini çok yönlü olarak etkilemektedir. Bu etkileşim ve işbirliği, görev ve sorumluluklar konusunda benzer değerlendirmeler yapılması gerektiğini düşündürmektedir.

Uygulama öğretmenlerinin ve öğretmen adaylarının açık uçlu olarak sorulan sorular doğrultusunda öğretmenlik uygulamasına ilişkin görüşleri belirlenmiştir. Bu kapsamda şu üç soru sorulmuştur:

- Uygulama öğretmeni için: Üniversite ile işbirliği yapılarak gerçekleştirilen öğretmenlik uygulamasını yapı ve işleyiş yönlerinden nasıl değerlendiriyorsunuz? (Lütfen yazınız.); Öğretmen adayı için: İlköğretim okullarıyla işbirliği yapılarak gerçekleştirilen öğretmenlik uygulamasını yapı ve işleyiş yönlerinden nasıl değerlendiriyorsunuz? (Lütfen yazınız.)

- Uygulama öğretmeni için: Genel olarak öğretmen adaylarının hazır bulunuşluk düzeyini nasıl değerlendiriyorsunuz? (Lütfen yazınız.); Öğretmen adayı için: Genel olarak uygulama öğretmenlerinin size sağladıkları katkıları nasıl değerlendiriyorsunuz? (Lütfen yazınız.)

- Uygulama öğretmeni için: Sizin de uygulama öğretmeni olarak görev aldığınız öğretmenlik uygulaması ile ilgili olarak ayrıca belirtmek istediğiniz hususlar varsa, yazınız; Öğretmen adayı için: Sizin de öğretmen adayı olarak görev aldığınız öğretmenlik uygulaması ile ilgili olarak ayrıca belirtmek istediğiniz hususlar varsa, yazınız

Uygulama öğretmenlerinin öğretmenlik uygulamasının yapı ve işleyişine ilişkin görüşleri:

Uygulama öğretmenleri; 
- Üniversitede uygulamadan sorumlu öğretim elemanının, öğretmen adaylarıyla uygulama öğretmenini tanıştırması ve öğretmen adaylarının derslerini izlemesi gerektiğini,

- Öğretmenlik uygulaması etkinliklerinin, üniversite ile yeterli düzeyde işbirliği yapılarak gerçekleştirilemediğini,

- Öğretmen adaylarının uygulama saatlerinin artırılması ve her y1 uygulama yapmalarının sağlanması gerektiğini,

- Öğretmenlik uygulaması etkinliklerinin, öğretmen adaylarının daha önceden öğrendikleri bilgileri sınıfta gerçekleştirmelerini sağladığını, varsa eksiklerini giderdiklerini, bu uygulamanın öğretmen adaylarının çocukları ve mesleği sevmelerini sağladığını, öğrenilen teorik bilgilerin gerçek sınıf ortamında uygulandığını,

- Öğretmen adaylarından kendilerinin de yararlandığını,

- Öğretmen adaylarının I. dönem gözlem yaptıkları okul ile II. dönem uygulama yaptıkları okulun aynı olması gerektiğini,

- Uygulama öğretmenlerine sınıf yönetimi teknikleri, aktif katılım, öğretmenlik becerilerinin geliştirilmesi gibi konularda üniversiteler tarafından hizmet içi eğitim programları düzenlenmesi gerektiğini,

- Eğitim fakültelerinin bünyesinde uygulama okullarının bulunması gerektiğini,

- Öğretmen adaylarının öğretim sürecinde sunu planları üzerinde gereğinden fazla durduklarını ifade etmişlerdir.

Uygulama öğretmenlerinin öğretmen adaylarının hazır bulunuşluk düzeyine ilişkin görüşleri:

Uygulama öğretmenleri;

- Önceki yıllara göre son yıllardaki öğretmen adaylarının mesleği sevdiğini, öğretmen adaylarının derse hazırlanarak geldiklerini, üstlendikleri görevleri en iyi şekilde yapmaya çalıştıklarını; ancak bunun yanı sıra mesleği önemsemeyenlerin de olduğunu, öğretmen adaylarının amacına uygun bir şekilde ders işlediklerini ve hedeflenen davranışa büyük ölçüde ulaştıklarını,

- Öğretmen adaylarının bilgi birikimlerinin çok iyi olduğunu; ancak en önemli eksikliğin uygulama olduğunu bunun da aşılacağına inandıklarını, ders sunumları ve sinıf yönetimi konusunda zamanla deneyim kazanacaklarını,

- Öğretmen adaylarının üniversitedeki derslerinin ve KPSS sınavlarına hazırlık çalışmalarının, hazır bulunuşluklarını olumsuz yönde etkilediğini, 
- Üniversitelerde öğretmen adaylarının akademik ve mesleki yeterlikleri dışında kişilik özellikleri, beceri eğitimi, motivasyon, kendini geliştirme, öğretim yapabilme gibi konuların üzerinde durulabileceğini, öğretmen adaylarının teorik donanıma sahip olduklarını; ancak üniversitedeki uygulama derslerinin artırılması gerektiğini belirtmişlerdir.

Uygulama öğretmenlerinin öğretmenlik uygulaması etkinliklerine iliş̧kin belirttikleri diğer görüşler:

Uygulama ögretmenleri;

- Öğretmenlik uygulaması etkinliklerinin haftada bir gün yerine daha uzun süreli olması gerektiğini, uygulamaların farklı derslerde ve farklı sınıflarda yapılması gerektiğini,

- Uygulamadan sorumlu öğretim elemanları ile işbirliği yapılarak öğretmen adaylarının değerlendirilmesi gerektiğini, bu konuda öğretim elemanlarıyla yeterli düzeyde işbirliğinin sağlanamadığını,

- Öğretmenlik uygulaması için oluşturulan grupların 1-2 öğretmen adayından oluşturulması gerektiğini,

- Öğretmen adaylarının, uygulama okulundaki çalışmaları ile üniversitedeki derslerini bir arada yürütmekte güçlük yaşadıklarını, bu dönemde kendilerini sadece öğretmenlik uygulamalarına vermeleri gerektiğini,

- Öğretmen adaylarının üniversitelerden temelde donanımlı olarak geldiklerini, güncel bilgi, beceri ve davranışları kazandıklarını ifade etmişlerdir.

Uygulama öğretmenleri açık uçlu sorulara yönelik cevaplarında özellikle, üniversitede uygulamadan sorumlu öğretim elemanları ile yeterli işbirliğini sağlayamadıklarını belirtmişlerdir. Uygulama öğretmenleri, öğretmen adaylarının uygulama sürelerinin uzatılarak, bu dönemde sadece öğretmenlik uygulaması etkinlikleriyle ilgilenmeleri, üniversite eğitimlerinde daha çok uygulamaya yer verilmesi gerektiğini belirtmişlerdir.

Buna göre, özellikle öğretim elemanları ile uygulama öğretmenleri arasında etkili bir iletişim ve işbirliğinin sağlanması, öğretmen adaylarının eğitiminde teorik bilgilerin yanı sıra gerçek yaşama dayalı, somut uygulamalara önem verilmesi öğretmenlik uygulaması etkinliklerinin etkililiği açısından önemli görülmektedir.

Öğretmenlik uygulaması dersinin planlanan amaçlara ulaşabilmesi, üniversite öğretim elemanı ile uygulama öğretmeni ve öğretmen adayı arasındaki etkileşim ve işbirliğinin geliştirilmesine bağlıdır. Ancak 
böylelikle karşılaşılan sorunlara çözüm önerilerinin geliştirilebilmesi ve daha nitelikli öğretmenlerin yetiştirilmesi sağlanabilecektir.

Öğretmen adaylarının öğretmenlik uygulamasının yapı ve işleyişine ilişkin görüşleri:

Ögretmen adaylarl;

- Öğretmenlik uygulaması için gidilen okullardaki uygulama öğretmenlerinin uygulamanın nedenleri ve amaçları konusunda daha fazla bilgilendirilmesi, uygulama öğretmenlerinin gerekli dikkat ve özeni göstermeleri konusunda yönlendirilmeleri, uygulama okullarının ve uygulama öğretmenlerinin seçilmesinde daha dikkatli davranılması gerektiğini,

- Öğretmenlik uygulaması etkinliklerinin farklı düzeylerdeki sınıflarda, farklı okullarda (köy okulları gibi) yapılmasını,

- Üniversitede uygulamadan sorumlu öğretim elemanları tarafindan daha sık denetim yapılması, öğretim elemanları tarafindan ders uygulamalarının yeterince izlenmesi, uygulama öğretmeni ile sorumlu öğretim elemanı arasında etkin bir işbirliği olmasını,

- Öğretmenlik uygulamasının daha uzun süreli olmasını,

- Her sınıfa 1-2 öğretmen adayının verilmesini,

- Öğretmenlik uygulamasında, öğretim faaliyetleri dışında okulun yönetimi ile ilgili bilgi ve becerileri de kazanmaları gerektiğini,

- Uygulama öğretmenlerinin kendilerine önceden işlenen konuları sunmak üzere vermelerinden ve uygulama öğretmenleri tarafından verilen her türlü görevi üstlenmekten dolayı rahatsızlık duyduklarını,

- Uygulamanın kendilerine çok büyük yarar sağladığını, öğretmenlik mesleği ile ilgili birçok şey öğrendiklerini, kendilerine olan güvenlerinin arttığını, uygulanan planların kontrol edilip gerekli düzeltmelerin yapılmasının plan hazırlama konusunda oldukça yarar sağladığını ifade etmişlerdir.

Öğretmen adaylarının uygulama öğretmenlerinin kendilerine sağladığı katkılara ilişkin görüşleri:

Öğretmen adayları;

- Uygulama öğretmeninin nasıl bir yöntem ve teknik uyguladığı, ne tür etkinlikler ve pekiştireçler kullandığı gibi birçok konuda kendilerine fikir 
verdiğini, uygulama öğretmenlerinin karar verme sürecine katkıda bulunup yol gösterdiklerini, eleştirilerinin yapıcı olduğunu, hem kişilikleri hem de dersi sunuş biçimleriyle örnek alınabilecek bir model olduklarını, sınıf yönetiminin nasıl sağlanabileceğini, bireysel farklılıklar için nasıl bir yol izlenmesi gerektiği konusunda fikir verdiklerini,

- Uygulama öğretmenlerinin dersi bırakıp kendilerine boş zaman yaratmak hevesinde olduklarını, kendilerine pek fazla yardımc olmadıklarını, sadece eleştirdiklerini, gözlemlerini gizli tuttuklarını, uygulama öğretmenlerinin yeterli katkı getirmediğini, ancak öğretmen adaylarının onlara katkı sağladığını, zaman zaman meslekten soğutucu tavirlar sergilediklerini,

- Uygulama öğretmeninden öğretmen arkadaşlarına, öğrencilere, velilere ve okul çalışanlarına-asla- yapılmaması gerekenleri öğrendiklerini,

- Uygulama öğretmenlerinin kendilerine soru sorulduğu zaman yardımcı olduklarını,

- Kendilerine sağlanan katkının uygulama öğretmenine göre değiştiğini, uygulama öğretmeninin araç-gereç ve kaynakların sağlamasında yardımcı olduğunu; fakat öğretim yöntemi ve sınıf yönetimi konusunda yeterli katkıyı sağlayamadığını ifade etmişlerdir.

Öğretmen adaylarının öğretmenlik uygulaması etkinliklerine ilişkin diğer görüşleri:

Öğretmen adayları;

- Öğretmenlik uygulamasının yararlı olduğunu, uygulama deneyimi kazandıklarını, yeterli ve yetersiz yönlerini gördüklerini, öğretmenlik uygulaması sırasında öğretmenliğin uygulama boyutunu öğrendiklerini,

- Düzenli olarak, haftada bir gün, ilgili tarafların katılacağı bilgilendirme toplantılarının yapılmasını,

- Uygulama süresinin uzatılması, köy okullarında da uygulama etkinliklerinin yapılmasını,

- Öğretim elemanlarının öğretmen adaylarıyla işbirliği içinde olmasin1,

- Uygulama öğretmenlerinin seçilmesine gereken özen ve dikkatin gösterilmesi gerektiğini,

- Uygulamadan sorumlu öğretim elemanı ile uygulama öğretmeni arasındaki işbirliği ve etkileşimin geliştirilmesi gerektiğini ifade etmişlerdir.

Öğretmen adaylarının özellikle belirttikleri sorun, okul yöneticileri ve uygulama öğretmenlerinin kendilerine karşı ilgisiz davranmasıdır. Bu durum 
benzer araştırmalarda da saptanmıştır(Demircioğlu 2003; Talvitie, Peltokallio and Mannisto 2000). Bu nedenle, öğretmen adayları tarafından uygulama okulu ve öğretmenlerinin seçimine özen gösterilmesi gerektiği belirtilmiştir. Bunun yanı sıra öğretmen adayları, öğretim elemanları ile uygulama öğretmenleri arasında yeterli ve etkili iletişim sağlanamadığ üzerinde de durmuşlardır. Ayrıca uygulama etkinliklerinin süresinin uzatılması, köy okullarında da uygulama etkinliklerinin yürütülmesi, her bir sınıfa düşen öğretmen adayı sayısının azaltılması gerektiği, öğretmen adayları tarafından sıkça belirtilen görüşler olmuştur. Öğretmen adayları, öğretmenliğe başlamadan önce öğretmenlik uygulaması sürecini yaşamalarının, kendilerine olan güveni artırarak güçlü ve zayıf yönlerini keşfedebildiklerini ifade etmişlerdir.

Uygulama öğretmenleri ile öğretmen adaylarının açık uçlu sorulara verdikleri yanıtlardan, öğretmenlik uygulaması sürecinde planlanan işbirliği, etkileşim, görev ve sorumlulukların belirlenmesi, okul ve öğretmenlerin seçilmesi gibi konularda çeşitli sorunlar yaşandığı açıkça görülmektedir. Ortaya çıkan bulgular doğrultusunda, öğretmenlik uygulaması etkinliklerinin yeterli düzeyde gerçekleştirildiğinin söylenmesi oldukça güçtür. Öğretmenlik uygulaması sürecinin hedeflenen davranışları kazandırması ve amacına ulaşması, bu sorunların çözülmesine ve uygulama sürecinin geliştirilmesine bağlıdır.

\section{SONUÇLAR VE ÖNERILER}

Uygulama öğretmenlerinin ve öğretmen adaylarının görüşlerine dayalı olarak yapılan bu çalışmadan elde edilen bulguların çözümlenip yorumlanmasıyla ulaşılan sonuçlar ve öneriler aşağıda verilmiştir:

\section{Sonuçlar}

Öğretmen adaylarının yaklaşık üçte biri, uygulamadan önce her zaman uygulama öğretmenlerinin kendilerini izleyerek bilgi ve deneyim kazanmalarını sağladığını, uygulama öğretmenlerinin çoğu zaman sınıftaki öğrencileri kendileriyle tanıştırarak etkileşim kurulmasını sağladığını, öğretmen adayları tarafından gerçekleştirilen sınıf içi etkinliklerin uygulama öğretmenleri tarafından değerlendirildiğini ve uygulama öğretmenlerinin ders işlerken her zaman onları gözlemlediğini ifade etmiştir.

Öğretmen adaylarının yaklaşık üçte biri, uygulama öğretmenlerini nitelikli bir model olarak gördüklerini belirtmişlerdir.

Öğretmen adaylarının özellikle, uygulama öğretmenlerinin öğretmen adaylarına öğrencilerin hazır bulunuşluk düzeyleri, ilgi ve yetenekleri konusunda bilgi vermesi, ders planı hakkında bilgi vermesi, ders planının hazırlanmasında öğretmen adayıyla etkileşimde bulunması, öğretmen adayının hazırladığı ders planını ve araç-gereçleri kontrol etmesi, öğretmen 
adayına pekiştireçler vermesi, değerlendirme sonuçları hakkında bilgi vermesi konusunda yeterli rehberliği alamadıkları görülmektedir.

Öğretmen adaylarının yaklaşık üçte biri, uygulama öğretmenleri tarafından okulun tanıtılmadığını, okuldaki diğer öğretmen ve yöneticilerle tanıştırılmadıklarını ifade etmişlerdir.

Uygulama öğretmenlerinin yarıdan fazlası, öğretmenlik uygulaması etkinliklerinde kendilerinden beklenen görev ve sorumlulukları, her zaman ya da çoğu zaman gerçekleştirdiklerini belirtmiştir.

Öğretmen adayları ve uygulama öğretmenleri tarafindan, uygulamadan sorumlu öğretim elemanı ile uygulama öğretmeni arasındaki işbirliğinin yeterli düzeyde olmadığı ifade edilmiştir.

Uygulama öğretmenleri, öğretmen adaylarının uygulama sürelerinin uzatılarak sadece öğretmenlik uygulaması etkinlikleriyle ilgilenmelerinin sağlanması, üniversite eğitimlerinde daha çok uygulamaya yer verilmesi gerektiğini belirtmişlerdir.

Öğretmen adaylarının özellikle belirttikleri sorun, okul yöneticileri ve uygulama öğretmenlerinin kendilerine karşı ilgisiz davranması olmuştur.

Öğretmen adayları tarafından uygulama okulu ve öğretmenlerinin seçimine özen gösterilmesi gerektiği, bunun yanı sıra öğretim elemanları ile uygulama ögrretmenleri arasında yeterli ve etkili iletişim kurulamadığı belirtilmiş̧tir.

Öğretmen adayları tarafından uygulama etkinliklerinin süresinin uzatılması, köy okullarında da uygulama etkinliklerinin yürütülmesi, her bir sınıfa düşen öğretmen adayı sayısının azaltılması gerektiği belirtilmiştir.

Öğretmen adayları, öğretmenliğe başlamadan önce öğretmenlik uygulaması sürecini yaşamalarının, kendilerine olan güveni artırdığını, güçlü ve zayıf yönlerini keşfedebildiklerini ifade etmişlerdir.

Uygulama öğretmenleri ile öğretmen adaylarının, öğretmenlik uygulaması etkinliklerine ilişkin görüşleri arasında, uygulama öğretmenleri lehine anlamlı bir farklılık saptanmıştır.

\section{Öneriler}

Öğretmen aday1, uygulama öğretmeni ve üniversitede uygulamadan sorumlu öğretim elemanı arasında etkili bir iletişim ve işbirliği sağlanmalıdır. Bu amaçla, her öğretim yılı başında ilgili tüm tarafların katılacağı etkinlikler gerçekleştirilmelidir. 
Öğretmenlik uygulamasının süresi uzatılmalıdır. Öğretmenlik uygulaması etkinlikleri haftada bir gün yerine haftada iki gün şeklinde gerçekleştirilebilir.

Öğretmen adayları, öğretmenlik uygulaması kapsamında öğretim elemanları tarafından, yapacakları çalışmalar hakkında kapsamlı bir biçimde bilgilendirilmeli, uygulama okullarına gidilip adayların sunularının izlenmesinin yanı sıra, her hafta düzenli bir biçimde geribildirim ve bilgilendirme toplantıları yapılmalıdır. $\mathrm{Bu}$ toplantılara, uygulama öğretmenlerinin de katılması önemli ve gerekli görülmektedir.

Uygulama öğretmenleri, öğretmenlik uygulaması etkinlikleri ve kendilerinden beklenen görev ve sorumluluklar hakkında, üniversitede uygulamadan sorumlu öğretim elemanları tarafından bilgilendirilmelidir. $\mathrm{Bu}$ amaçla, uygulama etkinlikleri öncesinde okul yöneticileri ve uygulama öğretmenlerine yönelik seminerler düzenlenmelidir.

Uygulama etkinlikleri öncesinde öğretmen adayları, sorumlu öğretim elemanları tarafından uygulama öğretmenleriyle tanıştırılmalıdır.

Öğretmen adaylarına birbirinden farklı nitelikteki okullarda uygulama yapabilmeleri olanağı verilmeli, özellikle yakın çevredeki köy okullarında da öğretmenlik uygulaması etkinliklerini gerçekleştirmeleri sağlanmalıdır.

Öğretmen adaylarının üniversitede aldıkları eğitim etkinliklerinde, gerçek yaşama dayalı uygulamalı etkinliklere daha fazla ağırlık verilmelidir. Üniversitede gerçekleştirilen uygulama etkinliklerine ilköğretim okullarından da öğretmenler davet edilmeli, onlardan öğrencilerin uygulama etkinliklerine ilişkin görüş ve önerileri alınmalıdır.

Okul yöneticisi ile üniversitedeki öğretim elemanı, öğretmenlik uygulaması etkinliklerinde görev almak isteyen öğretmenleri birlikte belirlemeli, özellikle istekli ve ilgili öğretmenlerin seçilmesine özen gösterilmelidir. $\mathrm{Bu}$ amaçla, her öğretim yılı başında uygulama etkinliklerinde görev almak isteyen öğretmenler, geliştirilen bir anket formu ile belirlenmelidir.

Üniversitelerin öğretmen yetiştiren fakülteleri, okullardaki uygulama öğretmenlerinin mesleki yönden gelişmelerini sağlayıcı yeni yöntem, teknik ve yaklaşımları kazandırmaya yönelik programlar düzenleyerek, bu alandaki işbirliğini geliştirmelidir.

Öğretmenlik uygulaması sürecinin gerçekleştirildiği okullarda, öğretmen adayları ve uygulama öğretmenlerinin gözlemlenebileceği araştırmalar yapılarak, öğretmenlik uygulamasının geliştirilmesi yönünde çalışmalar yapılmalıdır. 


\section{KAYNAKLAR}

Brooks, V. and Sikes, P. (1997).The good mentor guide: initial teacher education in secondary schools. Buckingham-Philadelphia: Open University Press.

Demircioğlu, İ. H. (2003). Tarih uygulama öğrencilerinin uygulama öğretmenleri ve uygulama okulları hakkındaki görüşleri: KTÜ Fatih Eğitim Fakültesi örneği. Firat Üniversitesi Sosyal Bilimler Dergisi, (13), 1,185-192.

Edwards, A. ve Collion, J. (1996). Mentoring and developing practice in primaryschools: supporting student teacher learning in schools. Buckingham-Philadelphia: Open University Press.

Jones, L., Reid, D. ve Bevins, S. (1997). Teachers' perceptions of mentoring in a collaborative model of initial teacher training. Journal of Education for Teaching, (23), 3, 253.

Kiraz, E. (2002). Öğretmen adaylarının hizmet öncesi mesleki gelişiminde uygulama öğretmenlerinin işlevi. Eğitim Bilimleri ve Uygulama, (1), 2, 183-196.

Talvitie, U., Peltokallio, L. ve Mannito, P. (2000). Student teachers' views about their relationships with university supervisors, cooperating teachers and peer student teachers. Scandinavian Journal of Educational Research, (64), 1, 79-88.

Ünver, G. ve Eroğlu, G. (2003). Uygulama öğretmeninin öğretmen adayına karşı davranış1. Eğitim Bilimleri ve Uygulama, (2), 3, 15-29.

Villani, S. (2002). Mentoring programs for new teachers: models of induction and support. California: Corwin Press Inc. A Sage Publications Company.

Zachary, L. J. (2000). The mentor's guide: facilitating effective learning relationships. San Francisco: Jossey-Bass. 